\title{
RFID を用いた低価格な農作業記録自動収集システムの開発
}

\author{
村上幸一 *1）・安藤瑞希 2) - 今村元紀 1）・宮本美佑 ${ }^{3 ）}$ - \\ スラメットクリスタントティルトウトモモ ${ }^{4)}$
}

1）香川高等専門学校 電気情報工学科 $\quad$ ₹ 761-8058 香川県高松市勅使町 355

2）奈良先端科学技術大学院大学 情報科学研究科 $=$ 6 630-0101 奈良県生駒市高山町 8916 番地 5

3）徳島大学 電気電子工学科 $=770-8501$ 徳島県徳島市新蔵町 2 丁目 24 番地

4）東京大学大学院 学際情報学府 $=113-8654$ 東京都文京区本郷 7 丁目 3-1

\begin{abstract}
要旨
農業の IT 化に伴い，クラウドサービスを用いて作業記録を行ら事例が增えてきた．しかし，情報入力の手間 がシステム普及のネックとなっている. 本研究グループでは, 農作業記録の自動化による作業記録の省力化を目 指し，農作業データを自動で取得するシステム及びその取得データから農作業を推定する手法を提案した，具体 的には，長距離交信が可能な UHF 帯の RFID（Radio Frequency IDentification）タグを, 戋場内の道具, 場所, 品 種（を示す札）に貼り，農作業データを取得した，取得データに対してナイーブベイズ分類器を適用して農作業 を推定しサーバ上へ記録した．本システムは農業現場への普及を意識し，低価格な構成での開発を行った．本論 では提案システムの構成とシステムを用いた実証実験の結果について報告する。
\end{abstract}

キーワード

RFID，農作業の自動記録，低価格，機械学習，N/E 比分析

\section{はじめに}

農業では，生産管理や人件費の算出のために作業記録を 取る必要がある。従来は紙媒体に記録をしていたが，管理 や保存, 過去データとの比較が困難なため, 現在では SaaS 型のクラウドサービス（以下，「クラウドサービス」 とする。）を用いた農作業記録システムの導入が進めら机 ている。 スラメットら（2012）や，クラウド農業生産管理 システム $(<$ http://agri-s.com>, 2017 年 5 月 15 日参照) など, 多くの研究機関・IT ベンダから農作業日誌をクラウドサー ビス上で記録するシステムが提供されている。しかしこれ らシステムを用いた農作業記録は, 通常, 農作業終了後に 農作業とは別でデータ入力作業を行うこととなる。 そのた めこの農作業後のデータ入力の負担がシステム普及のネッ クになっていると考光られた.

記録作業の負担を低減させる研究として, 中西ら（2013）

* Corresponding Author

E-mail: murakami@t.kagawa-nct.ac.jp
の固場センサネットワークを用いるものがある。このシス テムは作業を行らことで変化する戋場の状態（温度・土㙋 の電気伝導度等）をセンサで検知することで, 行った作業 の推定を行らシステムである. しかし, 実際に作業を特定 するためには多くの種類のセンサを必要とし, コストが高 くなるといら問題点があった。 また土壤に複数のセンサ （pH センサ, 土壊水分センサ, 栄養センサなど）が接触す る場合, 土㙋は導電体である（水分を含んでいる）ためセ ンサ間で干渉（クロストーク）が発生する恐れもあった.

別の研究として, 南石ら（2007）の短距離通信の RFID を用いる研究がある。このシステムはRFID と呼ばれる非 接触で情報のやり取りを行ら技術を用いて，固場に設置し た ICカードから情報を取得するものである。 システムの 試作と基礎的な試験が行われたが，農業現場への技術普及 を目的としたその後の低価格化システムの開発の試みは行 われていない.

本研究の目的は，農作業データを自動で取得するシステ ム及びその取得データから農作業を推定するシステムの開 発である，さらに農業現場への普及のために，低価格化や 
利用の動機付けを目的とした応用アプリケーションについ ても検討した。本論文ではこれらを総称して，農作業記録 自動収集システム（以下，「提案システム」とする.）と呼 ぶ. 提案システムは農作業中に品種や場所, 使用している 道具などの農作業データを取得し，そのデータから農作業 を推定することができる。データの取得には通信距離が $1 \mathrm{~m}$ 程度の RFID を用いた。 RF タグ（以下，「タグ」とする。） を戋場各地や道具に貼り付け，RFIDリーダを携帯しなが ら農作業を行らことで農作業データを取得できる．作業の 推定はRFID を用いて収集したデータを教師データとした 分類器を作成することで行った. なお本論では一人の農作 業熟練者を対象に教師データを収集し, 別サイクルの実験 に扣いて同一人物を対象に認識実験を実施した. そのため, 本論では「人 (作業者)の違い」についての問題を取り扱っ ていない。ただし, 初心者・熟練者の比較など将来的な検 討に備えての機能を, 応用アプリケーションの検討に招い て示した.

\section{RFID}

\section{RFID について}

RFID（Radio Frequency IDentification）とは誘導電磁界ま たは電波によって，非接触で半導体メモリのデータを読み 出し, 書き込みのために近距離通信を行うものの総称であ る（大見 2008）。近年では図書館業務の自動化（辻 2005）, 物品のトレーサビリティなど幅広い分野で応用されてい る. RFID はデータを保存するタグ，タグのデータの読み 出し・書き込みを行らリーダ・ライタ，これらを制御する 上位システムで構成される（図 1)。また上位システムが リーダ・ライタに内蔵されている製品も存在する.

他の ID システムとして, バーコードや QR コードが挙 ゲられる。これらのID システムはカメラでラベルを認識 するため，ラベル表面が励れている場合正しくデータを読 夕取ることができない。また一度印刷されてしまえば情報
を書き換えることもできないといった問題点があった． RFID は電磁波で交信するためタグの表面が污れていても 正しくデータを読み取ることができる。またタグ自体がメ モリを持つため情報を書き換えることも可能である。ささら に既存の ID システムと大きく異なる点はラベルに狙いを 定めなくても，容易にデータを読み取ることができること である.

以上のことから, RFID は本研究の目的である新たな作 業記録の入力方法として有用な技術であると考兄られる. しかし，RFID はタグの使用周波数帯・電力供給方式，リー ダ・ライタのアンテナ方式等により特性が大きく異なる. そのため, 要素毎での比較検討を行い本研究に適した RFIDを選定した。

\section{$\mathrm{RF}$ タグの周波数帯}

電波は周波数帯によって図2 のように分類される。 RFID として主に利用される周波数は LF 帯, HF 帯, UHF 帯, SHF 帯である。 タグの使用周波数帯によって，指向性， 通信速度，通信距離，水への透過性，リーダ・ライタのア ンテナサイズが変化する. 各周波数帯の違いを表 1 に示す

表 1 RF タグの使用周波数帯による特徵

\begin{tabular}{lcccc}
\hline 周波数 & $\mathrm{LF}$ & $\mathrm{HF}$ & $\mathrm{UHF}$ & $\mathrm{SHF}$ \\
\hline 指向性 & 弱 & 中 & 中 & 強 \\
\hline 通信速度 & 低速 & 中 & 中 & 高速 \\
\hline 通信距離 & 数十 $\mathrm{cm}$ & 数十 $\mathrm{cm}$ & 約 $5 \mathrm{~m}$ & 約 $1 \mathrm{~m}$ \\
\hline 水の透過性 & 高 & 高 & 中 & 低 \\
\hline アンテナサイズ & 大 & 中 & 中 & 小 \\
\hline 電磁ノイズの影響 & 大 & 中 & 小 & 小 \\
\hline 電力伝送方式 & 電磁誘導方式 & \multicolumn{2}{c}{ 電波方式 }
\end{tabular}

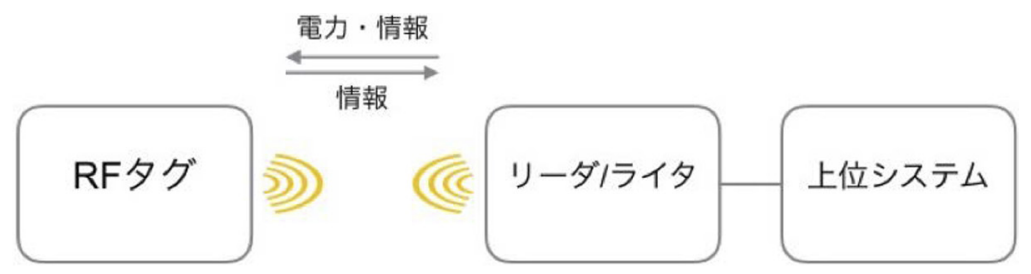

図 1 RFID システムの構成図

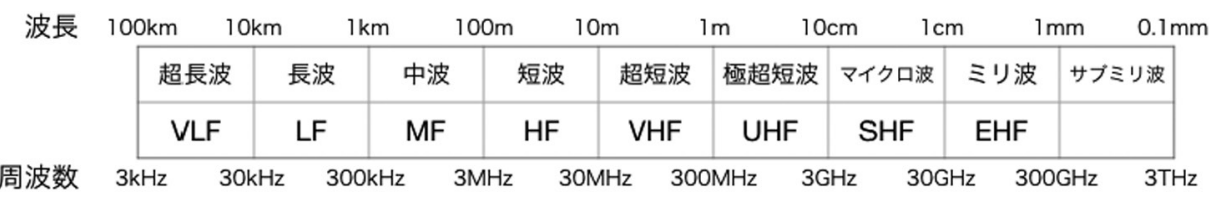

図 2 周波数による電磁波の分類 
（SmartGrid ニューズレター編集部 2006）。なお通信距離は 日本の電波法令に基づき使用した場合の最大通信距離の目 安である.

一般的に周波数が高くなるにつれて指向性が強まり，通 信速度も高まる. 逆に周波数が低くなると指向性は弱まり， 障害物に対して回りこむ力が強くなる。また，LF帯から UHF 帯の間に扣いては，周波数が高まるにつれて通信距 離が増加するが, SHF 帯では電波の回り込みが起こりに くくなるためUHF 帯に比べ通信距離が減衰する。ささらに, アンテナ長は波長に比例するため, 高周波になるにつれて タグ, リーダ・ライタは小型になる。

\section{RF タグの電源方式}

タグは電源方式の違いにより，パッシブ方式，セミパッ シブ方式，アクティブ方式の 3 種類に分類される（一般社 団法人日本自動認識システム協会 2016). 各電源方式の比 較及びタグのイメージ図をそれぞれ表2 と図3 亿示す。 パッ シブ方式はリーダ・ライタからの電力供給でのみ駆動する 受動型であるのに対して，セミパッシブ方式は交信時のみ リーダ・ライタからの供給電力で駆動し，センシングはタ グに内蔵された電池で行ら受動型である. アクティブ方式 は全てタグに内蔵された電池でセンシング・交信を行う. 交信距離は受動型が数 $\mathrm{m}$ 程度であるのに対して，能動型 であるアクティブ方式は数十 $\mathrm{m}$ にも及ぶ. セミパッシブ
方式・アクティブ方式はセンサと電池を内蔵しているため, 高価格で，タグ自体も大きくなってしまう。また，電池交 換等のメンテナンスも必要となってくる。 それに対して パッシブ方式は数十円から購入することができ，厚みも薄 くタグの基材として紙やプラスチックカードを使用するこ とができる。 またメンテナンスフリーといら長所を持つ。

\section{リーダ・ライタのアンテナ方式}

リーダ・ライタのアンテナ方式として，直線偏波方式と 円偏波方式が存在する(図 4)。まず直線偏波方式はリーダ・ ライタから直線偏波を放出しタグにアクセスする方式であ る。そのためリーダ・ライタと偏波方向に対してタグの向 きが平行でなければ交信距離が大きく減衰してしまう。こ れに対して円偏波方式はリーダ・ライタから円偏波を放出 しタグにアクセスする方式である。この方式はタグがリー ダ・ライタに対して平行であれば減衰はほぼ発生しない. しかし，直線偏波方式に比べると交信距離がやや短いと いった特徵がある。またタグの長手方向がアンテナに向い た場合は，偏波方式に関係なく交信距離が減衰する（一般 社団法人日本自動認識システム協会 2016, 大見 2008).

\section{RFID の選定}

使用する RFID を選定するにあたって以下の 3 点を考慮 した

表 2 RF タグの電源方式による特徵

\begin{tabular}{lccc}
\hline 電源方式 & パッシブ方式 & セミパッシブ方式 & アクティブ方式 \\
\hline 基本原理 & 受動型 & 受動型 & 能動型 \\
\hline 搭載電池 & 無 & 有 (センサ用 $)$ & 有 $($ セン・交信用 $)$ \\
\hline 交信距離 & 数 $\mathrm{mm} \sim$ 数 $\mathrm{m}$ & 数 $\mathrm{mm}$ 〜数 $\mathrm{m}$ & 数 $\mathrm{m}$ 数十 $\mathrm{m}$ \\
\hline タグの価格 & 低価格 & 高価格 & 高価格 \\
\hline 備考 & メンテナンスフリー & 電池の寿命管理が必要 & 電池の寿命管理が必要 \\
\hline
\end{tabular}

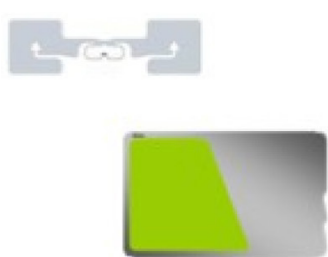

(1) パッシブ方式

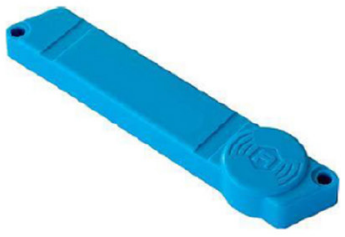

(2) セミパッシブ方式

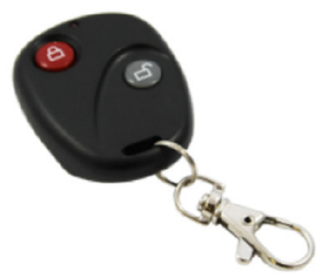

(3)アクティブ方式

図 3 各電源方式の RF タグの例

セミパッシブ方式（UHF Semi-passive Temperature Logger Tag）

http://www.gaorfid.com/RFIDbrochures/UHF_Semipassive_Temperature_Logger_Tag_116045.pdf（2017 年 5 月 15 日参照）

アクティブ方式（2.45 GHz Active Key Fob RFID Tag/Transponder） http://gaorfid.com/product/tag-transponder-key-fob-2-45-active-rfid/（2017 年月 15 日参照） 


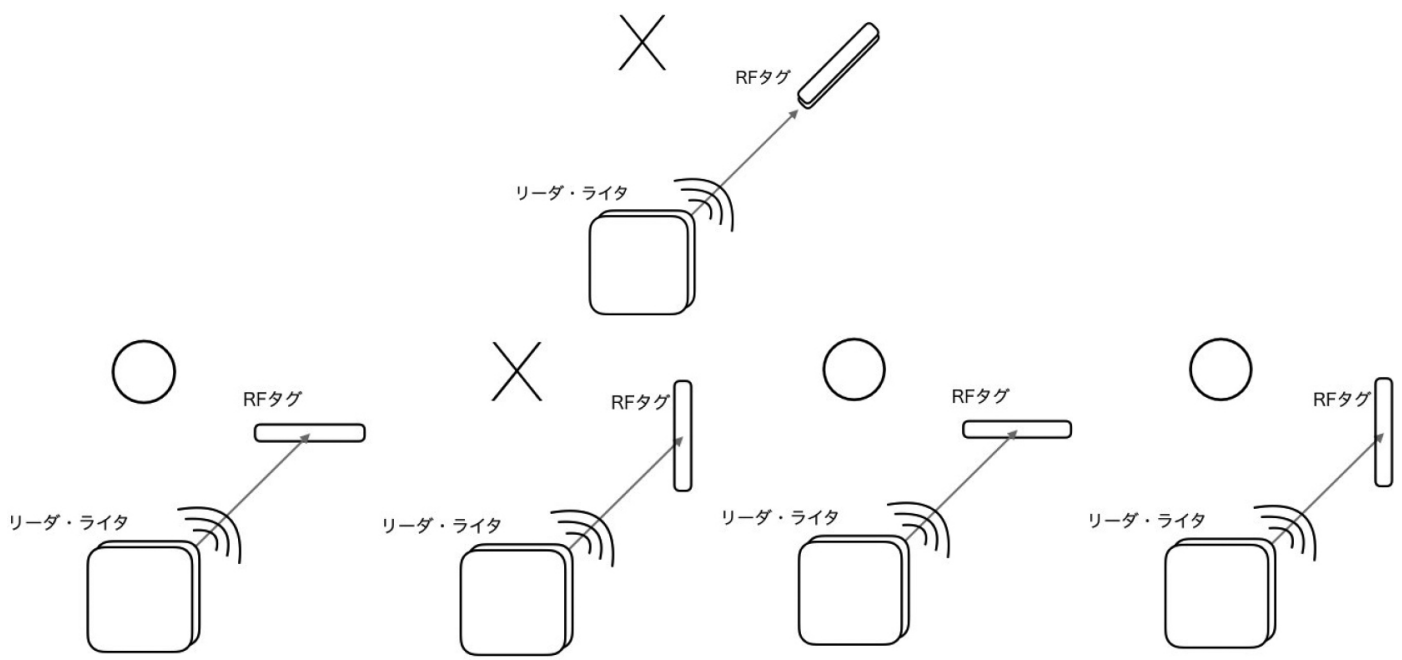

(1) 直線偏波方式

（2）円偏波方式

図 4 直線偏波と円偏波

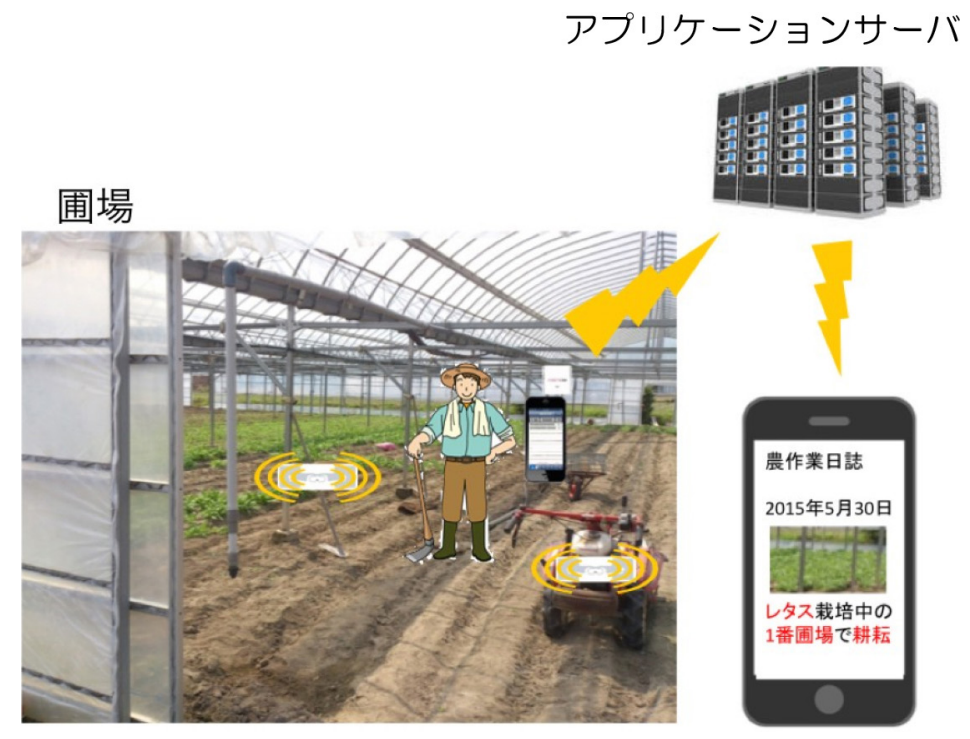

図 5 提案システムの概要

提案システムの概要図である。将来的には圃場の状態のカメラ撮影も想定しているが, 現在はまだカメラ撮影の機能は実装されていない,

・作業者の負担は最小限に抑光る.

・農作業には大きな動作が伴う。

・低価格でメンテナンスフリー

南石ら（2007）のシステムは通信距離が数 $\mathrm{cm}$ と短かっ たため，作業者はタグからの情報取得を意識する必要が あった。 この問題は通信距離の長い RFID に変更すること やタグを大量に配置することで解決できる。 また，農作業 時には大きな動作が伴らため, リーダの位置がずれても正 しくデータを取得できる必要がある. そのため円偏波方式 を用いることが適切である.更に農業現場普及のためには, 低価格でメンテナンスフリーであることが望ましい，その ためにはパッシブ方式が望ましい.

\section{提案システムの実装}

\section{システム全体の概要}

図 5 に本研究の提案システムの全体図を示す。本システ ムは，RFIDを用いてタグからデータを取得する RFID シ ステム，RFID システムから送られてきたタグデータを集 約するアプリケーションサーバ, タグデータを処理して作 業を分類する推定アルゴリズム，推定した結果をスマート フォン・PC 上で表示する表示システムで構成される。

まず，RFID システムは UHF 帯の RFID とiOS のデバイ スで構成される。本研究で使用した RFIDリーダとタグを 図 6 亿示寸。本研究では円偏波方式の RFID リーダである 


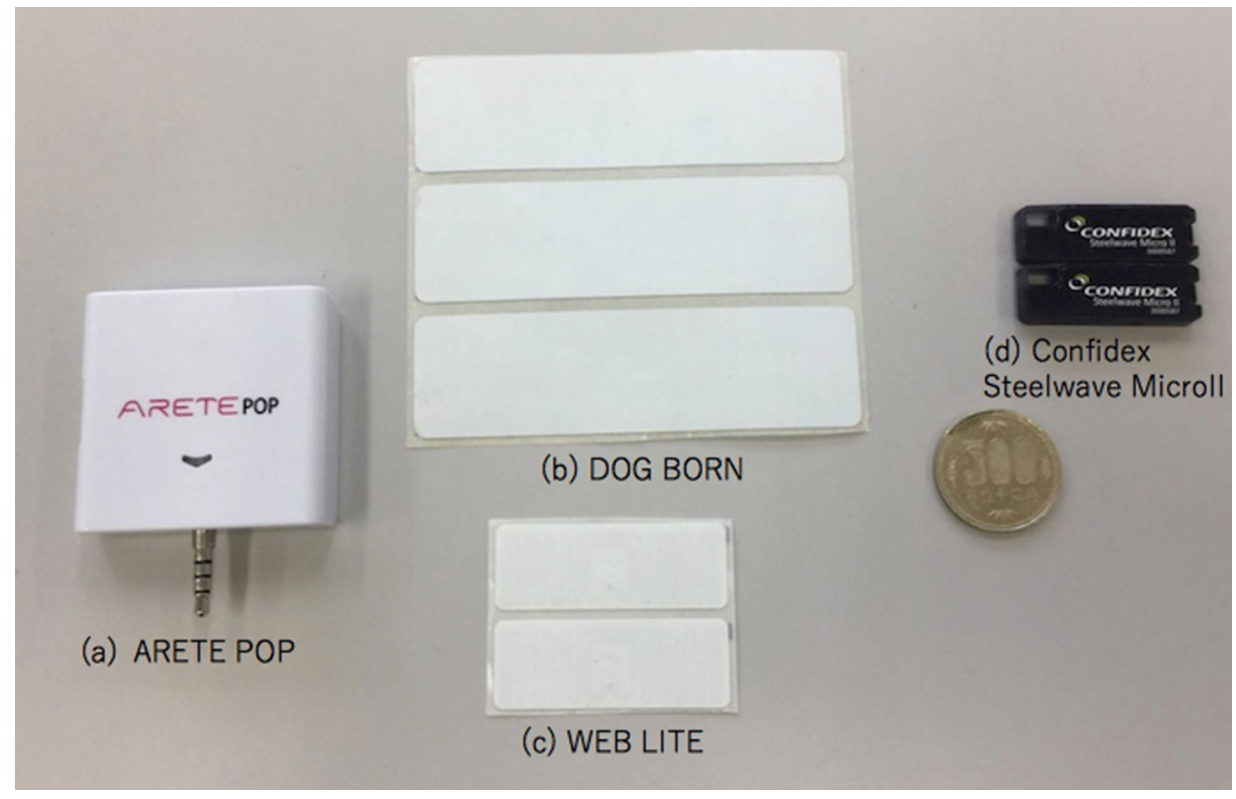

図 6 使用した RFID リーダ及びRF タグ

ARETE POP (<http://www.hk-rfid.com/arete-pop-rfid-donglereader>, 2017 年 5 月 15 日参照）とUHF 帯域でパッシブ 形式のタグである SMARTRAC 社の DOGBORN (<https:// www.smartrac-group.com/dogbone.html>, 2017 年 5 月 15 日 参照), 同じく SMARTRAC 社の WEB LITE (<https://www. smartrac-group.com/web-lite.html>, 2017 年 10 月 12 日参照), Confidex 社の Confidex Steelwave MicroII ( $<$ http://www.confidex. com/products/smart-identification/confided-steelwave-micro-iinfc-tag>，2017 年 5 月 15 日参照）を使用した。 プロトタ イプで実験を行った際，金属部に貼り付けたDOGBORN は正しくデータを取得することができなかった。そこで， 冷蔵庫の金属部には交信距離の減衰を低減させるため, Confidex 社の金属用タグを使用した。 また，DOGBORN の貼り付けが難しい小さな道具に対しては WEB LITEを 用いた。 RFID リーダ 1 台とタグ 100 枚 (DOGBORN 80 枚, WEB LITE 20 枚), 金属用タグ 10 枚のセットで 5 万円以 下であり低価格で導入することができる。 またiOS デバ イスではスリープをせずに使用することを前提としてい る。そのため使用前には $\operatorname{iOS}$ デバイスのフル充電が必要 となる。本システムは, タグにデータの書き込み・書き換 えを行ら機能, RFIDリーダを携帯して作業を行らことで 戋場内に設置したタグからデータを取得する機能，取得し たデータを CSVファイルで出力する機能を有している.

\section{農作業の推定アルゴリズム}

検出したタグのデータから農作業を推定するアルゴリズ ムについては，機械学習が使用されている，機械学習とは ユーザがすべての情報を明示的にプログラムしなくても学 習する機能をコンピュータに与える技術である。 RFID シ ステムで出力された CSVファイルからユーザが行った作 業を推定する機能を有する。推定アルゴリズムは学習パー トと推定パートの2つに分けられる。学習パートでは，実
際に行った作業名と出力された CSVファイルを入力する ことで，作業とデータ間の関係を学習する. 推定パートで は，学習パートで使用したファイルとは別の CSVファイ ルを入力することで，そのデータに対して一番尤もらしい 作業の名前を出力する.

\section{RFID システム}

本提案システムの流れを図 7 亿示す。本研究では,「太 陽光利用型植物工場」で「葉物野菜（コマッナ）」を栽培 する際の「播種・定植・収穫」作業の推定を対象とした. まず圃場内の道具, 場所, 品種にタグを設置した。なお， 場所タグを設置する時はタグの長手方向が作業者に向かな いように注意した。道具タグは, 収穫用のプラスチック製 のトレイ, 播種用の発泡スチロール製のトレイ, 計量器, 冷蔵庫, 水道, 袋詰め用のケース, 苗を管理する保温庫, 机, 八サミに貼り付けた。実際に設置したタグを図 8 に示す。 楕円で囲んだものがタグである。（a）のタグは戒場のどの 区画で作業をしているかを表して扣り，作業者の腰の高さ に合わせて設置した。（b）のタグは水道や机で作業すると きに座る椅子に貼り付けた。（c）のタグは播種・収穫時に 使用するトレイに貼り付けられたものである. タグは耐水 性にも優れているため，タグを貼り付けたまま道具を洗ら ことが可能である．品種タグは作物を定植した区画に小型 の立て札を設置し，そこに貼り付けた。品種タグでは，作 目名と品種名を管理するが 1 作目 1 品種のみの栽培の場合 には，作目名のみを管理する。それぞれのタグには 0001 や0081などのIDを割り振った。固場を表すタグには 0001 から 0040 を, 品種を表すタグには 0051 から 0060 を, 道具を表すタグには 0081 から 0090 の ID を割り振った。

データの取得は作成したアプリケーションで行った。 ず作業者は図 9 のようにARETE POPを装着したiOS デバ 


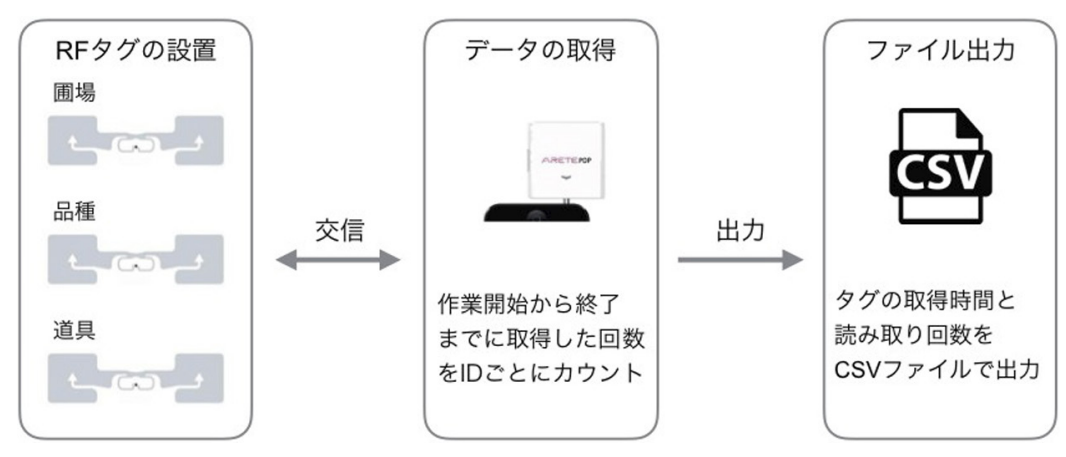

図 7 RFID システムの構成

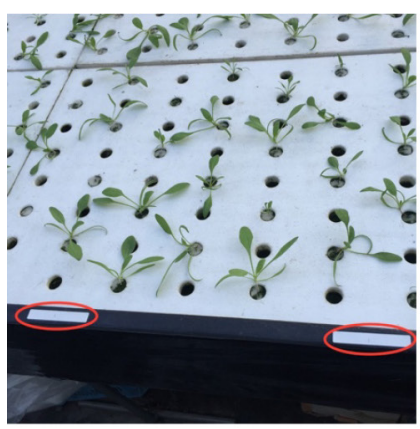

（a）固場タグ

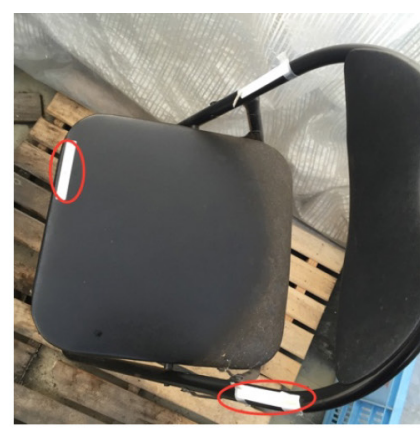

（b）場所タグ

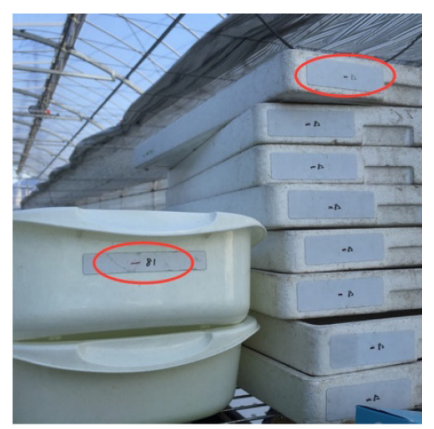

(c) 道具タグ

図 $8 \mathrm{RF}$ タグの設置例

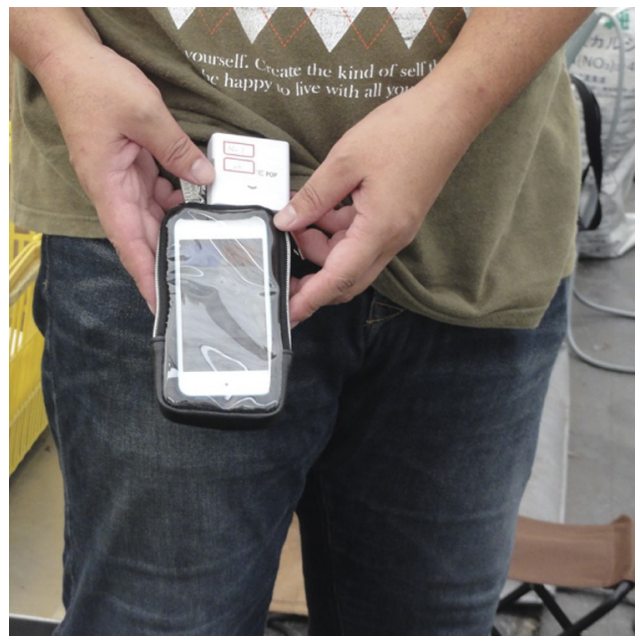

図 9 RFID システムの携帯イメージ

イスを腰に携帯する. その後アプリケーションを起動して 作業を開始する。アプリケーションの表示画面を図 10 に 示す。まずアプリを起動すると（a）の画面が立ち上がる. 下部中央のトグルスイッチをオン（緑）にすることで, RFID リーダが iOS デバイス上で認識される. 次に赤い作 業開始のボタンを押すことで（b）のようにタグの読み取 りが開始される.読み取り距離は数 $\mathrm{mm}$ から約 $1 \mathrm{~m}$ である. 作業が終了したら青い作業終了ボタンを押すことで CSV
ファイルが出力される. 作業者は作業の開始や区切りを意 識して，作業ごとに作業開始時に赤い作業開始ボタンを， 作業終了時には青い作業終了ボタンを押寸必要がある. (c) はアプリの設定画面で，動作パラメータは電波の出力レベ ルやタグの読み取り間隔を変更できる. 制御パラメータで はタグを何枚読み取ったら CSVファイルを出力するかを 設定することができる，読み込み音はタグを読み取った時 のビープ音を $\mathrm{ON} / \mathrm{OFF}$ する機能である.

$\mathrm{CSV}$ ファイルは2 種類の形式で出力される. 1つ目は図 11 (a) のように出力される。 この形式では一定数のタグ を読み取る毎に新しい行に移る。図 11 では100タグ毎に 改行するよらに設定した。（1）は読み取り開始時刻と 100 タグ読み取り終えた時の時刻を表している。（2）はタグの ID とその ID が読み取られた回数を示している.（a）を用 いて説明すると, 2015 年 10 月 23 日 13 時 41 分 4 秒から 42 分 8 秒の間にID0085 のタグが 16 回読み取られたこと を表している. 100 タグごとに行を区切ることによってタ グの検知回数を相対的に見ることができる．これによりタ グとすれ違っただけか，長時間携帯していたのかを見分け ることができる.

2 つ目の形式は 1 つ目の形式の 1 行 1 行を詳しく保存す る形式で（b）のよらに出力される，100タグ全ての読み 取り時間を記録しており, より詳細に作業の流れを分析す ることができる。（b）を実際に分析してみると，0002（圃 場の区画) タグと 0089 (八サミ) タグが読み込まれている. 

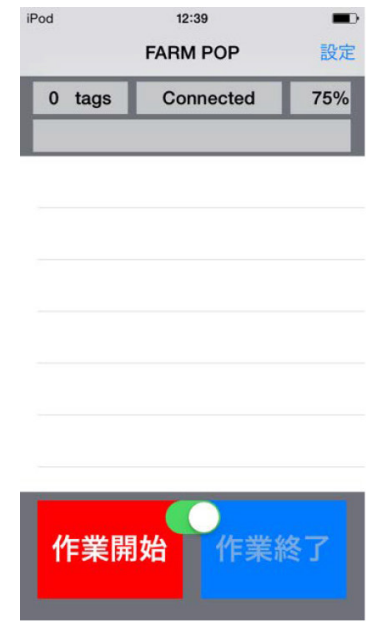

(a) 起動画面

\begin{tabular}{|l|r|r|}
\hline iPod $₹$ & \multicolumn{1}{c|}{$\begin{array}{c}17: 04 \\
\text { FARM POP }\end{array}$} \\
\hline $\mathbf{5}$ tags & Plugged & $\mathbf{1 0 0 \%}$ \\
\hline & 探索中 (184) \\
\hline 0081 & & 114 \\
\hline 0084 & 10 \\
\hline 0085 & 9 \\
\hline 0088 & 50 \\
\hline 0051 & & 10 \\
\hline
\end{tabular}

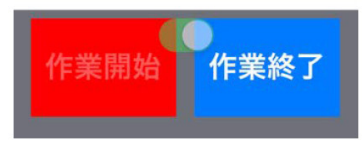

(b) 読み取り画面

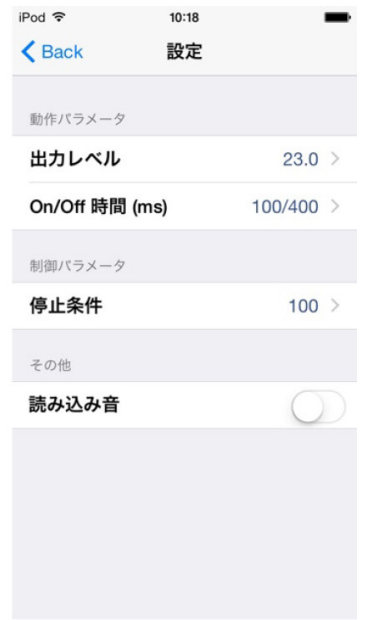

(c) 設定画面

図 10 アプリケーションの表示画面

(1)

時刻
(2)

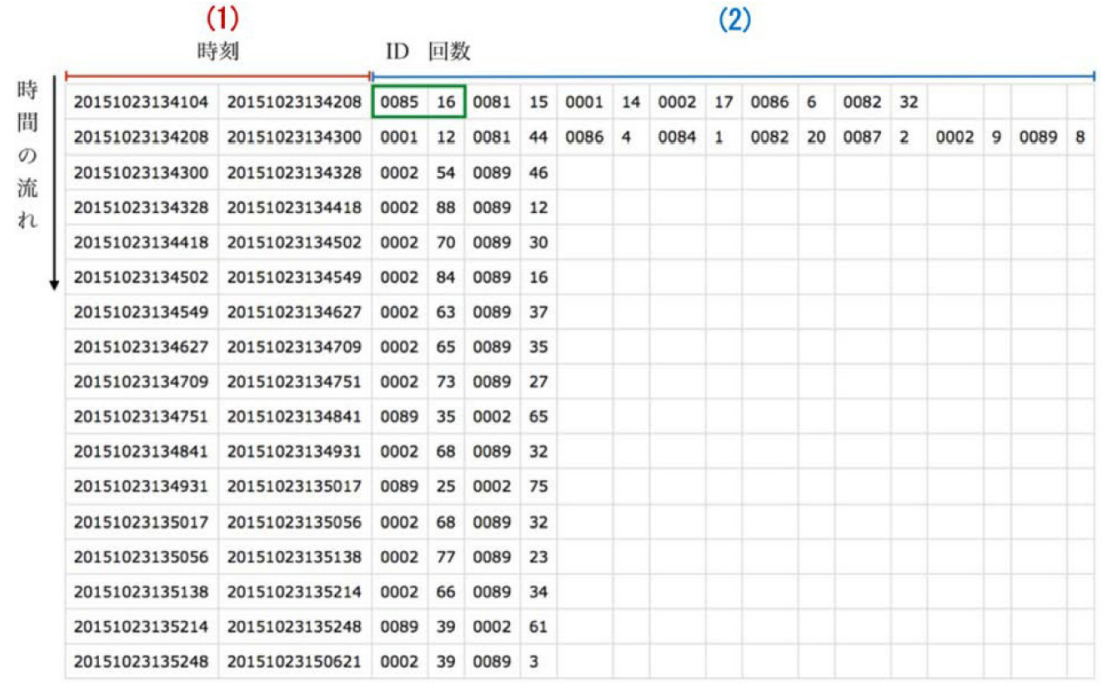

（a）各タグの読み取り回数情報 （例は 100 タグごとで改行）

\begin{tabular}{|l|l|}
\hline 20151023135258 & 0002 \\
\hline 20151023135258 & 0002 \\
\hline 20151023135259 & 0002 \\
\hline 20151023135259 & 0002 \\
\hline 20151023135300 & 0002 \\
\hline 20151023135300 & 0002 \\
\hline 20151023135301 & 0002 \\
\hline 20151023135301 & 0002 \\
\hline 20151023135301 & 0089 \\
\hline 20151023135302 & 0002 \\
\hline 20151023135302 & 0002 \\
\hline 20151023135303 & 0002 \\
\hline 20151023135303 & 0002 \\
\hline 20151023135304 & 0089 \\
\hline 20151023135304 & 0002 \\
\hline 20151023135304 & 0002 \\
\hline
\end{tabular}

(b) 読み取りタグの 詳細情報

\section{図11ＣSVファイルの情報}

このデータから戋場の 0002 とら場所で八サミを使い収 穫を行っていることがわかる.

\section{推定アルゴリズム}

前述のと抢り，タグからのデータは作業している区画を 表す圃場データ，コマッナやレタスなど育てている作目・ 品種を表す品種データ, 使用している道具を表す道具デー タの 3 種類に分類される. しかし農業の特徵として考慮し

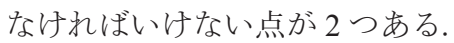

$1 つ$ 目は同じ品種であっても時期によって育てる区画が
変わる点である，例としては，気温が高くなった時，長時 間の直射日光を避けるために育てる区画を変更する．2つ 目は同じ区画であっても時期によって育てる品種が変わる 点である. 品種によって旬が異なるからである. そのため, 場所や品種の情報は作業を推定するための情報として扱う ことが難しいことがわかる.

そこで，まず道具タグの情報のみで推定を行い，後から 場所と品種の情報を付け加える方法で作業を推定した. 道 具タグでの推定にはナイーブベイズ分類器 (Naive Bayes classifier）（Lewis and Ringuette 1994）を用いた. 圃場と品 
種情報は，読み取ったデータの全圃場データと品種データ を比較してそれぞれ一番検出頻度が高かったものを採用 した.

ナイーブベイズ分類器とは分類問題をベイズの定理を 使って解く手法で，スパムフィルタ等のテキスト・データ マイニングの分野で使われている（小島 2006）。特徵量間 の依存性を考慮することはできないが，比較的少ない教師 データで訓練を行うことができる。農業では 1 工程が長く 学習用のデータが少ないためこの手法を用いた．今回は データを播種・定植・収穫の 3 つのカゴリに分類した。

分類に使用する特徵量 (説明変数) は, トレイ 2 種, 計 量器, 冷蔵庫, 水道, 袋, 保温庫, 八サミ, 固場の 10 種 類である.アルゴリズムの学習の手順を以下に示す.

1. 各カテゴリの特徴量の検知割合を求める.

例：播種（トレイ $1: 0.2 \%$, トレイ $2: 40 \%$, 計量器 : $0 \%, \cdots \cdots)$

2. 全カテゴリの特徵量の検知割合を求める.

3. 各カテゴリの特徵量の得点を（1）式より求める.

得点 $P_{i j}=\log \frac{\text { カテゴリ } C_{i} \text { での特徵量 } F_{j} \text { の検知割合 }}{\text { 全カテゴリでの特徵量 } F_{j} \text { の検知割合 }}$

$$
\begin{aligned}
& C_{i}(i=1-3): \text { カテゴリ } \\
& F_{j}(j=1-10): \text { 特徵量 } \\
& P_{i j}(i=1-3, j=1-10): \text { 得点 }
\end{aligned}
$$

アルゴリズムの学習終了後は, 新しく取得したデータの各 特徵量の検知回数 $N_{j}(j=1-10)$ を求め, 各カテゴリの $P_{i j}$ と $N_{j}$ の積和を $j=1-10$ の範囲で求めた. その結果をカ テゴリ同士で比較して一番大きな值のカテゴリを分類結果 として出力した.

\section{アプリケーションサーバ}

\section{サーバ機能}

サーバ機能のフォルダ構成図を図 12 に示す.

RFID システムから送信されたタグのデータは, farmpop （各農園用フォルダ）にあるzipフォルダに蓄積される. 図 12 では, 3 つの農園（Farm A, Farm B, Farm C）用のフォ ルダがあることがわかり，それぞれに zip フォルダが存在 する。そして farmpopserver/GetGuessWorkName.phpにより 同階層の Python コードを実行することで，農作業の推定 を行う。

FarmPopList.php により，作業判定した結果をまとめた 一覧表を生成した（図 13）。各農園のデータはフォルダ （Farm A, Farm B, Farm C）ごとに区分されているため，対 応した農園の一覧表が表示される。また「グラフ」といら リンクをクリックすることで，後述する N/E比グラフ （Kurosu et al. 2002）を表示することができる.

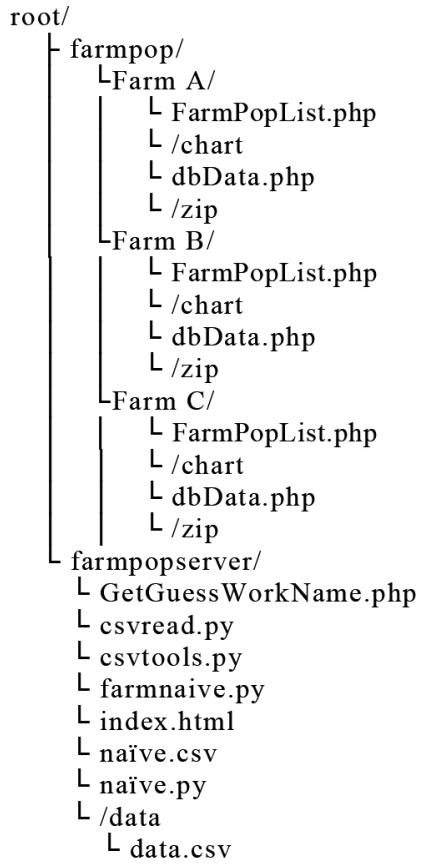

(a) アプリケーションサーバ

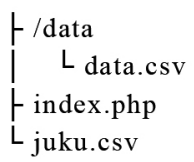

(b) $\mathrm{N} / \mathrm{E}$ 比グラフ表示機能

図 12 システムのデータ構成図

\section{N/E 比グラフ表示機能}

アプリケーションサーバでは, RFID システムより送信 されたデータを $\mathrm{N} / \mathrm{E}$ 比グラフとして表示することができ る. 農業法人の多くでは, 繁忙期にパートタイム労働者を 雇用することが多いが，経験の違いによってパートタイム 労㗢者の農作業技術にはバラッキがある。そこで農作業の 習熟度の低い初心者（Novice）（以下，初心者）と農作業 熟練者（Expert）（以下，「熟練者」とする.）の作業効率 をタグ検知数と作業時間から比較することで, 初心者の作 業効率の改善を行う。各作業で用いた農機具ごとにタグ データを取得することが可能であるため，より細かな粒度 で初心者の作業の改善点を発見することができる. 初心者 の本システム利用の動機付けとし，現場普及を進めること を狙いとして開発した。加えて初心者と熟練者では作業手 順などが異なる可能性がある。そのため教師データの学習 を別々に行って精度を上げる必要もあると考兄られる。N/ $\mathrm{E}$ 比グラフは，こ机ら作業者の違いを考慮するための将来 的な検討に備えての機能でもある.

本研究では Googlecharts（<https://developers.google.com/ chart/interactive/docs/gallery/barchart>, 2017年 5 月 17 日参照) を用いて実装した。 


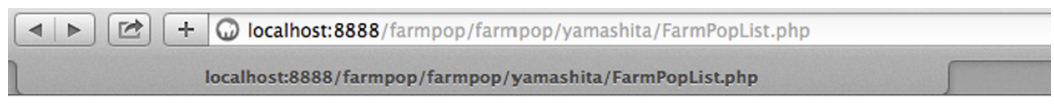

\section{FarmPopからのデータ一覧}

\begin{tabular}{|c|c|c|c|c|c|c|}
\hline 開始時間 & 終了時間 & 選択作荣名 & 判定作策名（サーパ） & データ & 判定 & N/E比 \\
\hline 11/23 08:13 & $11 / 2309: 21$ & 収䅘 & 収楼 & 20161123081351.zip & $\circ$ & ダラフ \\
\hline $11 / 2510: 23$ & $11 / 2511: 44$ & 収楼 & 定植 & 20161125102307.zip & $x$ & グラフ \\
\hline $12 / 12 \quad 15: 02$ & $12 / 1215: 49$ & 収䅹 & 定植 & 20161212150229.zip & $x$ & グラフ \\
\hline $12 / 2009: 11$ & $12 / 2009: 30$ & 播種 & 播種 & 20161220091133.zip & $\circ$ & ダラフ \\
\hline $12 / 2809: 51$ & $12 / 2810: 02$ & 播種 & 播種 & 20161228095100.zip & $\circ$ & ダラフ \\
\hline $01 / 0709: 28$ & $01 / 0709: 46$ & 5 播種 & 播種 & 20170107092840.zip & $\circ$ & グラフ \\
\hline $11 / 2709: 14$ & $11 / 2709: 17$ & 定植 & 定植 & 20161127091415.zip & $\circ$ & グラフ \\
\hline $12 / 2009: 01$ & $12 / 2009: 09$ & 定植 & 定植 & 20161220090120.zip & $\circ$ & グラフ \\
\hline $12 / 2309: 23$ & $12 / 2309: 44$ & 定植 & 定植 & 20161223092305.zip & $\circ$ & グラフ \\
\hline
\end{tabular}

図 13 各作業の判定結果及び N/E 比グラフ表示のためのリンク

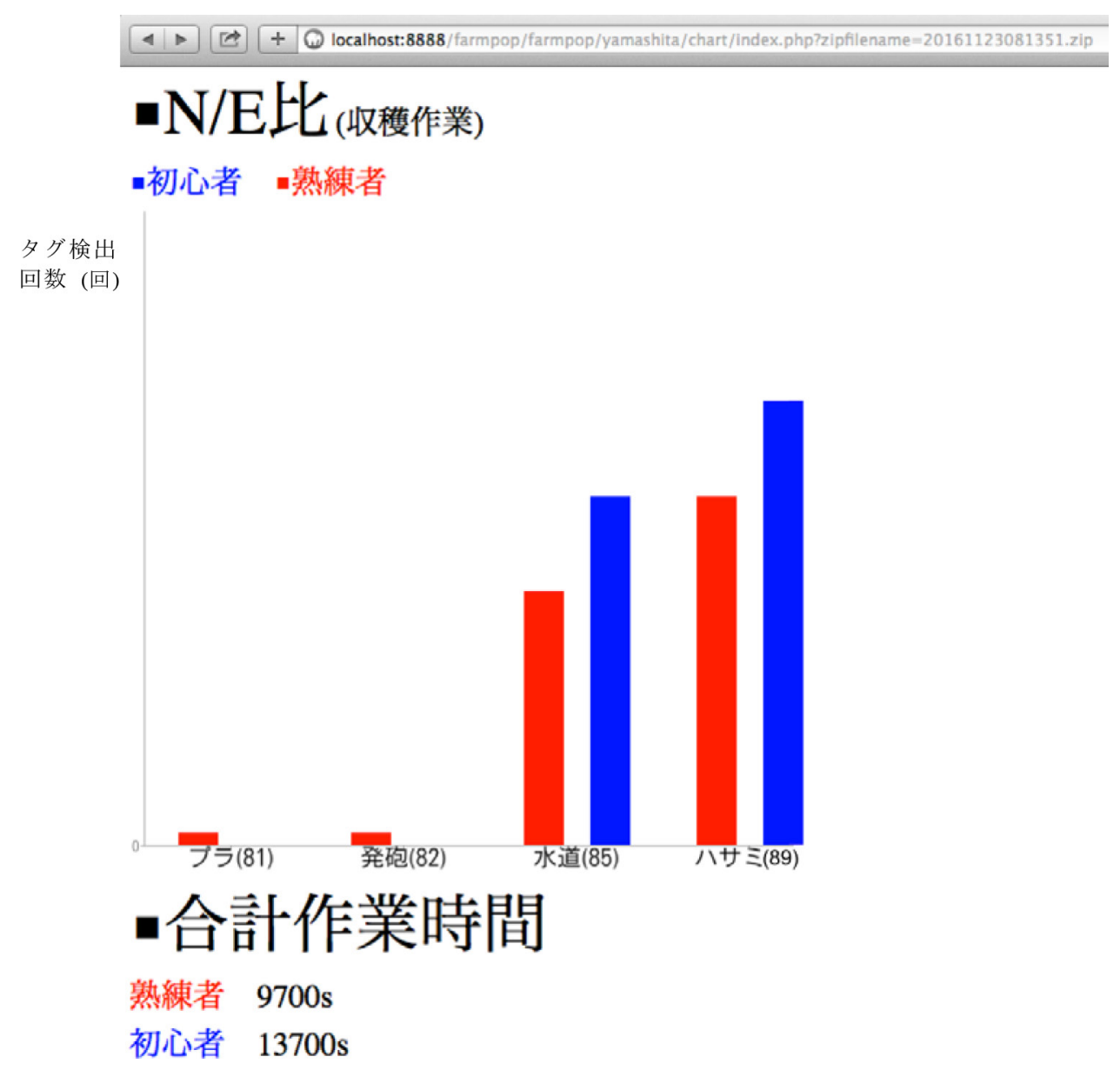

図 $14 \quad \mathrm{~N} / \mathrm{E}$ 比グラフ例

図 14 に $/ E$ 比グラフの読み方の説明のための, 仮想的 なデータによる表示例を示す。図 14 の表示例からは,

1. 初心者よりも熟練者の方が作業時間が短かった。

2. 収穫の作業に招いて，熟練者（赤）はプラスチック と発砲スチロールのトレイを少なからず使用したが,
初心者（青）は使用しなかった。

3. 八サミ，水道を利用した作業に拈いて熟練者（赤） の方が初心者（青）よりも効率的に作業をした.

ことなどが読み取れる。なお今回の実証実験は熟練営農者 1 名で運営する太陽光型植物工場で行ったため, N/E 比グ 
ラフ表示機能のユーザビリティー評価については行ってい ない.

\section{実験}

\section{実験内容}

本研究で提案した RFID システム及び推定アルゴリズム の有用性を確かめるために実験を行った，RFID システム については再現率と適合率についての実験を行った，再現 率とは，取得すべきデータをどの程度取得できたかの割合 のことで, 情報の抽出率を表す。適合率とは, 取得したデー タの中でどれだけ不要なタグのデータが入っていないかの 割合のことで，システムの正確さを表す。前述したナイー ブベイズ分類器は取得したデータが正確でなければ分類精 度が低くなるため，本システムでは適合率が重要となる。 再現率と適合率はそれぞれ以下の式で求めることができ る，検知すべきタグとは，作業で使用する場所や道具のこ とで, 各作業での検知すべきタグの一覧を表 3 にまとめた.

再現率 $=\frac{\text { 検知したタグの中の検知すべきタグの種類数 }}{\text { 検知すべきタグの種類数 }}$

適合率 $=\frac{\text { 検知したタグの中の検知すべきタグの種類数 }}{\text { 検知したタグの種類数 }}$

推定アルゴリズムについては分類器の性能についての実 験を行った。 RFID システムを用いて取得したデータの一 部を教師データとして分類器を作成した。 その後残りの データを分類器に掛けて，推定アルゴリズムの性能につい て検証した。

\section{RFID システム}

\section{実験条件}

RFID システムの実験条件を表 4 に示す。 タグは冷蔵庫 にConfidexを，八サミにWEBLITEを，それ以外には DOGBORNを使用した。 また今回は天候の影響を受けに くい施設園芸での実証実験を行った。農場の大まかな見取 り図及び，設置したタグの ID と区画の対応を図 15 に示 す。いずれのタグも作業者が携帯している RFID リーダと 同じ高さにタグを設置した。作業者がデータ取得開始前に 真值（これから行ら作業名，播種・定植など）を合わせて システム上に記録し，真值とデータのセットを教師データ とした

施設園芸農家（太陽光型植物工場, 水耕栽培にて葉物野 菜を栽培）で 1 週間 RFID システムを運用することで実験 用のデータを収集した。その結果，播種を 5 回分，定植を 5 回分, 収穫を 10 回分の計 20 回分の作業データが集まっ た。この作業から再現率と適合率を求めた。
表 3 検知すべき RF タグ

\begin{tabular}{ll}
\hline 作業名 & $\mathrm{RF}$ タグ \\
\hline 播種 & 発泡スチロール製のトレイ, 冷蔵庫, 水道, 保温庫, 机 \\
\hline 収穫 & $\begin{array}{l}\text { プラスチック製のトレイ, 発泡スチロール製のトレイ, } \\
\text { 計量器, 水道, 袋詰め用ケース, 机, ハサミ, 圃場 }\end{array}$ \\
\hline 定植 & 発泡スチロール製のトレイ, 水道, 保温庫, 机, 圃場 \\
\hline
\end{tabular}

\section{表 4 実験条件}

\begin{tabular}{|c|c|}
\hline RFID リーダ & ARETE POP \\
\hline RF タグ & $\begin{array}{l}\text { DOG BORN } \\
\text { WEB LITE } \\
\text { Confidex Steelwave MicroII }\end{array}$ \\
\hline 使用デバイス & iPod Touch 5（iOS 8.1.2） \\
\hline データ取得間隔 & $0.5[\mathrm{~s}]$ に 1 回 \\
\hline $\begin{array}{l}\mathrm{AP} \text { サーバヘのデータ } \\
\text { 送信タイミング }\end{array}$ & $\begin{array}{l}\text { デバイスでデータを一時記録, ユーザ任 } \\
\text { 意のタイミングで AP サーバへ送信 }\end{array}$ \\
\hline 農業形態 & 施設園芸（太陽光型植物工場, 水耕栽培） \\
\hline
\end{tabular}

\section{実験結果}

実験で取得したデータを表 5 に示す。各特徵量の読及取 り回数が 0 でなければ検知できているとして再現率と適合 率を求めた。

表 5 に対しての各作業と全体での再現率と適合率の平均 を表 6 に示す.

表 6 に示す全体の再現率 $47.9 \%$ と適合率 $88.1 \%$ は，実 験で収集したデータのうち, 88.1\% が正しいデータであり， この正しい $88.1 \%$ のデータは検知すべきデータ数全体の 47.9\%であることを意味する.

\section{考察}

各作業と全体の両方に扮いて, 再現率が適合率に比べ低 いことが確認できる。 これは冷蔵庫, 計量器, 机の検知率 が悪いことが原因である. 実験後の農家へのヒアリングで, 冷蔵庫は播種作業で種を取り出す際に 5 秒, 計量器は収穫 作業で 10 分以上，机は全作業に打いて 10 分以上使用され ることが分かった. データの取得は 1 秒に 2 回のペースで 行われるため, 1 回の作業で冷蔵庫は 10 回程度, 計量器 や机に関しては 1200 回程度は読み取られるはずである. 冷蔵庫は金属による影響を低減するため金属用のタグを使 用しているが，他のタグより交信距離が短いことを確認し た。また他のタグより使用している時間が短いことも農家 へのヒアリングでわかっている。これらが原因で冷蔵庫の 検知率が低くなったと考兄られる。しかし，計量器と机の 検知率が低い原因は明らかではない。推測としては，UHF 帯の電波は床や壁など様々なものに対して反射・吸収が行 われる。それにより，本来読み取られるべきタグが読み取 


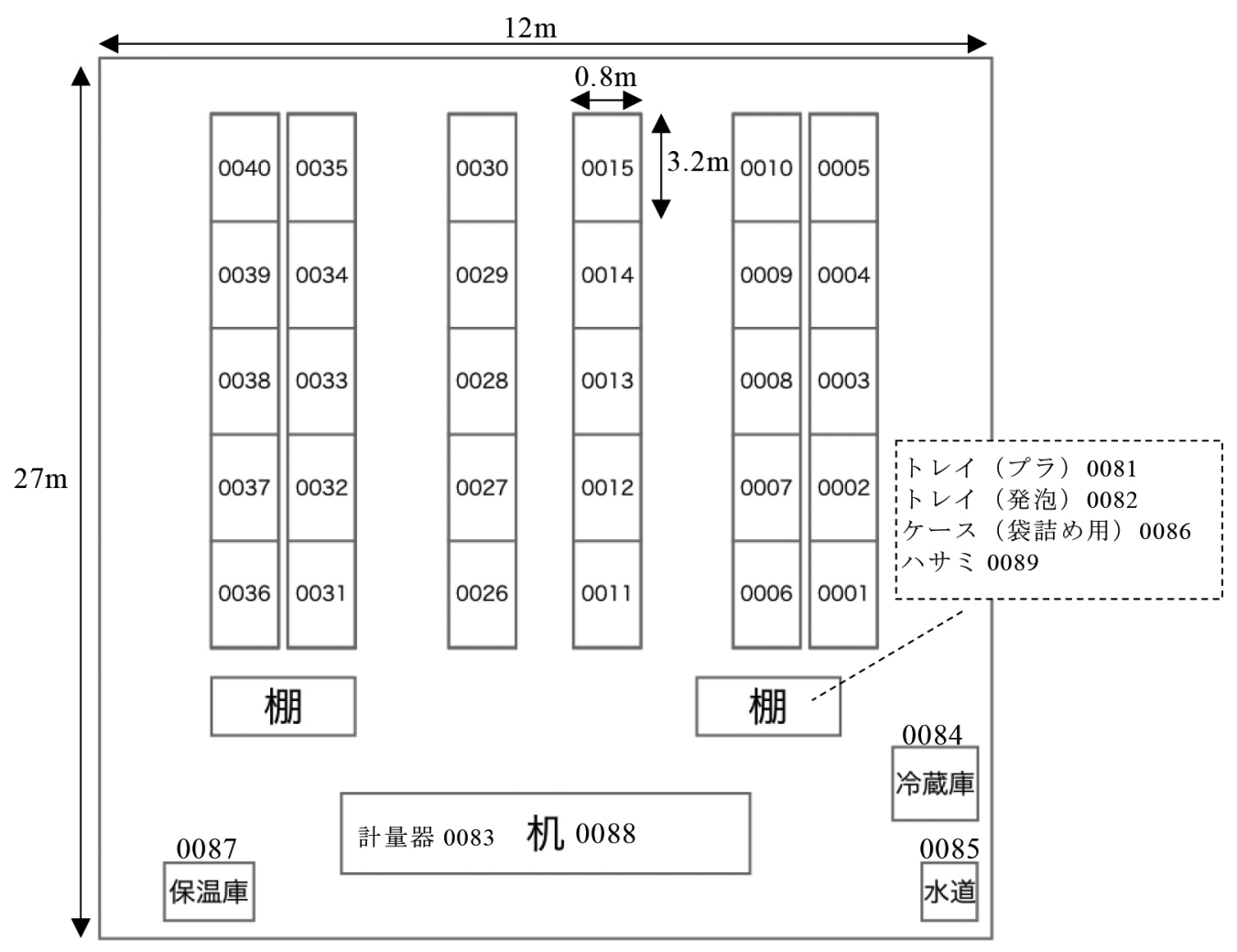

図 15 圃場の見取り図

図中の数字が，タグの ID 番号となる. 固場タグは $0001 〜 0040$ までとなる. 認識率向上のために同一番号のタグ 4 枚を一定の間隔を空 けて貼付している，冷蔵庫（0084）は金属用タグを 1 枚，水道（0085）は同一番号のタグを 3 枚，保温庫（0087）には同一番号のタグを 3 枚，机は同一番号のタグを 4 枚貼付している．机の上には計量器（0083）が置かれている. 計量器には同一番号のタグ 2 枚を貼付して いる.

2カ所の棚のぞちらかには，トレイ（プラスチック 0081），トレイ（発泡スチロール 0082），ケース（袋詰め用 0086），八サミ（0089）が 置かれる.トレイ及びケースには 4 枚の同一番号タグを貼付している. 八サミには 1 枚のタグを貼付している. 棚自体へのタグの貼付は 行っていない.

られないといった現象が発生するのだと思われる。

\section{推定アルゴリズム}

\section{実験条件}

実験条件は表 4 と同様である。推定アルゴリズムの学習 は表 5 で示した取得データを用いて行った。本実験のため に表 4 と同じ条件で再度 1 週間システムを運用し 15 回分 の作業データを収集した。 この 15 回分のデータに推定ア ルゴリズムを適用して推定精度を確認した。

\section{実験結果}

推定アルゴリズムの出力結果を表 7 に示す.

\section{考察}

推定の精度は $86.7 \%$ と再現率の低さは推定の精度にあ まり影響を与えていないことがわかる。水耕栽培では播種 と定植作業は数週間でまとめて行うことが多く, 今回, 播 種と定植のデータ数が少ないといら問題点があった。 しか し長期間システムを運用することでデータ数を増やし精度 をさらに上げることができると考える。またUHF 帯の電 波は床や壁に対して反射・吸収を起こすためタグの誤検知 は避けられない。そこで, 今回検知率の低かった特徵量に 関してはもら一度タグの配置位置を検討する必要がある。

\section{関連研究}

本章では, 提案システムと関連研究を比較し考察する. 南石ら（2007）のシステムは $2.45 \mathrm{GHz}$ と $13.56 \mathrm{MHz}$ の 2 種類の RFID 使用して抽り，交信距離は数 $\mathrm{cm}$ である. 手首に RFID リーダを装着して圃場施設や道具に貼り付け たタグを読み取ることで作業情報を取得する。このシステ ムは農作業時に手首に RFID リーダを装着するため, 作業 者の負担が大きくなる問題点がある. また，交信距離が極 めて短距離であるため, 作業者は意識せずにタグを読み取 ることが難しいといら問題点がある。特に國場施設の情報 を取得するためには，扉の持ち手等にタグを貼り付ける場 合が多いと思われるが，それでは室内限定での運用となっ てしまら，道具情報に関しても，ぞの道具を持っていると いら情報を得ることができるが，その道具を使ってどんな 作業をしているかの推定が困難といら問題がある. 例を挙 げると, 八サミを持っているといら情報を得ても, その情 報だけでは八サミを使って収穫を行っているのか，それと もただ八サミを洗っているだけなのかを特定することがで きない，

中西ら（2013）のシステムは戒場にセンサを設置して気 
表 5 取得データ

\begin{tabular}{|c|c|c|c|c|c|c|c|c|c|c|c|}
\hline No. & 作業 & プラ & 発泡 & 計量 & 冷蔵 & 水道 & 袋 & 保温 & 机 & ハサミ & 戋場 \\
\hline 1 & 播種 & 0 & 121 & 0 & 0 & 369 & 0 & 9 & 0 & 0 & 0 \\
\hline 2 & 播種 & 3 & 119 & 0 & 0 & 177 & 0 & 11 & 0 & 0 & 0 \\
\hline 3 & 播種 & 4 & 55 & 0 & 0 & 0 & 0 & 87 & 1 & 0 & 0 \\
\hline 4 & 播種 & 0 & 160 & 0 & 2 & 0 & 0 & 9 & 0 & 0 & 146 \\
\hline 5 & 播種 & 0 & 21 & 0 & 0 & 0 & 0 & 9 & 0 & 0 & 0 \\
\hline 6 & 収穫 & 188 & 176 & 0 & 0 & 70 & 0 & 3 & 0 & 38 & 337 \\
\hline 7 & 収穫 & 1,503 & 173 & 0 & 0 & 495 & 5 & 11 & 0 & 0 & 0 \\
\hline 8 & 収穫 & 581 & 464 & 2 & 0 & 794 & 865 & 6 & 0 & 54 & 613 \\
\hline 9 & 収穫 & 256 & 0 & 0 & 0 & 87 & 3 & 0 & 0 & 0 & 0 \\
\hline 10 & 收穫 & 310 & 1 & 0 & 0 & 40 & 0 & 0 & 0 & 0 & 1,644 \\
\hline 11 & 収穫 & 1,432 & 96 & 1 & 0 & 751 & 30 & 0 & 0 & 52 & 2,278 \\
\hline 12 & 収穫 & 167 & 4 & 0 & 0 & 611 & 1,070 & 0 & 0 & 202 & 218 \\
\hline 13 & 収穫 & 64 & 1 & 0 & 0 & 50 & 0 & 0 & 0 & 32 & 805 \\
\hline 14 & 収穫 & 0 & 0 & 0 & 0 & 0 & 0 & 0 & 0 & 0 & 276 \\
\hline 15 & 収穫 & 0 & 0 & 0 & 0 & 0 & 13 & 0 & 0 & 0 & 0 \\
\hline 16 & 定植 & 0 & 12 & 0 & 0 & 340 & 0 & 0 & 0 & 0 & 1,350 \\
\hline 17 & 定植 & 0 & 0 & 0 & 0 & 0 & 4 & 0 & 0 & 0 & 0 \\
\hline 18 & 定植 & 0 & 11 & 0 & 0 & 0 & 0 & 0 & 14 & 0 & 753 \\
\hline 19 & 定植 & 0 & 0 & 0 & 0 & 36 & 0 & 3 & 0 & 0 & 539 \\
\hline 20 & 定植 & 0 & 0 & 0 & 0 & 117 & 0 & 0 & 0 & 0 & 20 \\
\hline
\end{tabular}

表の略語は以下のものを意味する

プラ：プラスチック製のトレイ

発泡 : 発泡スチロール製のトレイ

計量: 計量器

冷蔵: 冷蔵庫

袋：袋詰め用のケース

保温 : 保温庫

\section{表 6 再現率と適合率}

\begin{tabular}{ccc}
\hline 作業 & 再現率 $[\%]$ & 適合率 $[\%]$ \\
\hline 播種 & 44.0 & 80.0 \\
\hline 収穫 & 53.8 & 97.1 \\
\hline 定植 & 40.0 & 80.0 \\
\hline 全体 & 47.9 & 88.1 \\
\hline
\end{tabular}

温・湿度や体積含水率，土壌の電気伝導度等の情報を取得 し作業を推定するといったものである. 作業者が何も道具 を持たずに作業を行光ることは大きなメリットではある が，考慮すべき要素が多くコストの面では多くの課題があ る。亦た例えば，ある作業をすることによって，温湿度や 土㙵の電気伝導度が変化することが分かっていても, 別の 要因によっても上昇する可能性もあり, 正確に作業を推定 するためにはより多くの他の情報と長期間の検証が必要と
なる。

これらのシステムに対して, 本提案システムは UHF 帯 の RFID を使用している. 通信距離が $1 \mathrm{~m}$ 程度であり, 作 業者はタグを触ろらと意識することなく，ハンズフリーで 作業を行らことができる。 また，自分の現在地と使用して いる道具の情報を同時に読及取ることができるため, どの 道具を使用しているかだけではなく，どの道具をなんの目 的で使用しているかまで推定することが可能である。ささら にタグは 1 枚あたり数十円で購入可能であり，リーダ・ラ イタから電力を供給するため低価格かつメンテナンスフ リーである。そのため非常に安価でシステムを構成するこ とができる。実験では 86.7\% の確率で作業を正しく分類 できることを確認した．現状の推定精度では分類の結果を 人の目で確認し修正する必要があるが，既存システムのよ らにパソコン等を用いて農作業後に手入力する必要がな く，作業時の負担もリーダの装着と開始時と終了時のボタ ンの押下のみと，十分作業を省力化できたと考えられる。 
表 7 推定結果

\begin{tabular}{|c|c|c|c|}
\hline No. & 真の作業 & 分類結果 & 推定結果 \\
\hline 1 & 播種 & 播種 & 0 \\
\hline 2 & 収穫 & 定植 & $\times$ \\
\hline 3 & 収穫 & 収穫 & 0 \\
\hline 4 & 収穫 & 収穫 & 0 \\
\hline 5 & 収穫 & 收穫 & $\bigcirc$ \\
\hline 6 & 収穫 & 収穫 & $\bigcirc$ \\
\hline 7 & 収穫 & 収穫 & 0 \\
\hline 8 & 播種 & 播種 & 0 \\
\hline 9 & 収穫 & 収穫 & 0 \\
\hline 10 & 収穫 & 収穫 & 0 \\
\hline 11 & 定植 & 収穫 & $\times$ \\
\hline 12 & 収穫 & 収穫 & 0 \\
\hline 13 & 収穫 & 収穫 & 0 \\
\hline 14 & 収穫 & 収穫 & 0 \\
\hline 15 & 収穫 & 収穫 & 0 \\
\hline
\end{tabular}

ただし今回モニタリングに協力して頂いた熟練営農者へ のヒアリングから, 操作性に関する以下の 3 つの問題点に ついても指摘を受けている.

（1）作業に集中していたら開始・終了ボタンを押すのを 忘れたり，予め作業を宣言（播種, 収穫など）しなければ ならないなど，農作業するらえで少々ストレスを感じた。

（2）レシーバの位置が腰回りでブラブラしているため, それがストレスになった。

（3）RFIDリーダの電波受信面が反対面だった場合は受 信できないので，そのあたりも作業中に意識しなければな らず少々ストレスに感じた。

（1）の問題点に関しては, 作業開始ボタン, 終了ボタン をなくし，ユーザが専用ソフトウェアをスマートフォンに インストールするのみで，後はソフトウェアがバックグラ ウンドでタグデータを収集し，アプリケーションサーバヘ データを自動送信するシステムへと改良することで改善 が可能である. 路線バスの現在位置情報を共有するシス テムではあるが, Naito and Tanaka (2017) のシステムが, Bluetooth タグとスマートフォンを利用してこれを実現し ており参考となる. また今回は実証実験のために, 教師デー 夕取得のための予めの作業宣言 (システム上での作業選択) が必要であったが, 実際の運用時には, 予めの作業宣言は 必要とならない，(2),（3）の問題点については, レシー バの携帯方法の変更や電波受信面の固定を行らことにより 改善できる.

\section{おわりに}

本稿では，クラウドサービスを用いたシステムの普及の
ネックとなっている情報入力の負担を低減するため, 農作 業情報の新しい入力方法を検討し，UHF 帯の RFID とナ イーブベイズ分類器を使い農作業を推定するシステムを提 案した，提案システムはハンズフリーでデータを取得する ことができ，安価で構成することが可能である，実験では $86.7 \%$ の精度で作業を分類できることを確認した。

本稿では「太陽光利用型植物工場」で「葉物野菜（コマ ツナ)」を栽培する際の「播種・定植・収穫」作業の推定 を対象とした。今後の研究方向として，施設園芸で栽培さ れる他作物への展開や, 露地栽培で行われる農作業への適 用について検討する.

今後の課題としては，まず作業者が異なった場合の検討 が必要となる。例えば初心者と熟練者とで習熟の程度が違 ら場合には, 習熟度の違いから作業手順・癖等が異なると 考光られる. そのため同一の教師データでは農作業推定が 困難となることが予想される. 作業者が異なった場合の推 定精度に関する検討や，教師データの切り替えなどが今後 必要となる。 また技術上の課題としては, 電波の反射や吸 収に対応したタグの配置の検討や, サポートベクターマシ ン等の他のアルゴリズムの使用, カメラ・加速度センサと の併用による分類精度の向上, N/E 比グラフのユーザビリ ティー評価, ソフトウェアのバックグラウンド化，レシー バの携帯方法及び電波受信面の固定方法などの検討などが 挙げられる.

\section{謝辞}

本研究は生研センター「革新的技術創造促進事業（異分 野融合共同研究)」の支援を受けました。ここに謝意を表 します。また実証実験にあたりましては，山下農園 山下 理俊様にご協力を頂きました。 ご厚意に深謝致します.

\section{引用文献}

一般社団法人日本自動認識システム協会（2016）RFID の基礎, $<$ http://www.jaisa.jp/about/pdfs/20161104rfd.pdf >， 2017 年 10 月 12 日参照.

小島國照（2006）第 4 回 押さえておきたいスパムフィルタの技, $<$ https://thinkit.co.jp/free/article/0611/8/4/>, 2017 年 5 月 15 日参照.

Kurosu, M., H. Urokohara and D. Sato (2002) NEM: Novice Expert ratio Method, <http://ueyesdesign.co.jp/case/paper/upa2002.pdf>, 2017 年 5 月 17 日参照.

Lewis, D. D. and M. Ringuette (1994) A Comparison of Two Learning Algorithms for Text Categorization, Proc. of the 3rd Annual Symposium on Document Analysis and Information Retrieval, 8193.

Naito, K. and K. Tanaka (2017) Proposal of a bus location system based on participatory sensing with BLE devices and smartphones, Proceeding of The 21st World Multi-Conference on Systemics, Cybernetics and Informatics, 105-110.

中西㧝・安井顕誠・原田史子・島川博光（2013）圃場センサネッ トワークを用いた農作業内容の推定, 情報科学技術フォーラ 
么講演論文集，4: 565-566.

南石晃明・菅原幸治・深津時広（2007）RFID を用いた農作業自

動認識システム，農業情報研究，16(3): 132-140.

大見孝吉（2008）「よくわかる RFID 電子タグの全て」，オーム社，

東京, 1-232 pp.

スラメットクリスタントティルトウトモ・村上幸一・重田和

弘（2012）ICT を用いた農作業日誌作成支援システムの開発,

電子情報通信学会技術研究報告, LOIS 470: 7-12.

SmartGrid ニューズレター編集部（2006）RFID の基礎と最新動向
（2）RFIDのしくみ（その 1）さまざまな RFID タグ，<http:// sgforum.impress.co.jp/article/650>，2017 年 5 月 15 日参照.

过雅寛（2005）図書館システムに打けるRFID技術の適用， $<$ https://www.intec.co.jp/company/itj/itj4/contents/14.pdf>, 2017 年 5 月 15 日参照.

$\begin{array}{lrl}\text { 受付日 } & 2017 \text { 年 } & 5 \text { 月 } 31 \text { 日 } \\ \text { 受理日 } & 2017 \text { 年 } & 8 \text { 月 } 17 \text { 日 } \\ \text { 担当分野 } & & \text { 工学分野 }\end{array}$

\title{
Development of a Low-cost System Using RFID for Automatic Collection of Agricultural Records
}

\author{
Yukikazu Murakami*1), Mizuki Ando'), Genki Imamura'1), \\ Miyu Miyamoto ${ }^{3)}$ and Slamet Kristanto Tirto Utomo ${ }^{4)}$ \\ 1) Department of Electrical and Computer Engineering, National Institute of Technology, \\ Kagawa College, 355 Chokushi, Takamatsu, Kagawa 761-8058, Japan \\ 2) Graduate School of Information Science, Nara Institute of Science and Technology, \\ 8916-5 Takayama, Ikoma, Nara 630-0101, Japan \\ 3) Department of Electrical and Electronic Engineering, Tokushima University, \\ 2-24, Shinkura, Tokushima 770-8501, Japan \\ 4) Graduate School of Interdisciplinary Information Studies, The University of Tokyo, \\ 7-3-1, Hongo, Bunkyo-ku, Tokyo 113-8654, Japan
}

\begin{abstract}
Much information is now stored "in the cloud", but time and labor to input information pose a bottleneck. Here, we propose a system for gathering environmental data automatically and estimating the work needed from the acquired data with the aim of reducing labor through the automation of farm work records. Our method obtains information using radio frequency identification in the UHF band and categorizes farm work using a naive Bayes classifier. To disseminate this system, we developed it with a low cost structure. In this paper we report the configuration of the proposed system and the results of a demonstration.
\end{abstract}

\section{Keywords}

RFID, automatic record, farm work, low price, machine learning, N/E ratio analysis

\footnotetext{
* Corresponding Author

E-mail: murakami@t.kagawa-nct.ac.jp
} 